\title{
The Let's Eat Healthy and Move at School program for adolescents in South Korea: Program design, implementation, and evaluation plan using intervention mapping
}

\author{
Jiyoung Park ${ }^{1}$, Gill A. Ten Hoor ${ }^{2}$, Seolhyang Baek ${ }^{3}$, Sochung Chung ${ }^{4}$, Yang-Hyun Kim ${ }^{5}$, Gahui Hwang ${ }^{6}$ \\ ${ }^{1}$ Assistant Professor, College of Nursing, Institute for Health Science Research, Inje University, Busan; ${ }^{2}$ Assistant Professor, Department of Work and Social \\ Psychology, Maastricht University, Maastricht, Netherlands; ${ }^{3}$ Professor, College of Nursing, Dongguk University, Gyeongju; ${ }^{4}$ Professor, Department of Pediatrics, \\ Konkuk University Medical Center, Konkuk University School of Medicine, Seoul; ${ }^{5}$ Associate Professor, Department of Family Medicine, Korea University Anam \\ Hospital, Korea University College of Medicine, Seoul; ${ }^{6}$ Graduate Student, College of Nursing, Yonsei University, Seoul, Korea
}

Purpose: This study aimed to systematically develop an obesity prevention program for adolescents to promote healthy eating and physical activity in schools. Methods: The development of the Let's Eat Healthy and Move at School program for adolescents followed the six steps of intervention mapping (IM). IM is a widely used protocol for developing systematic and effective interventions based on theories and evidence. Results: To better understand the problem and identify the needs of adolescents, interviews were conducted with teachers, school nurses, and students (step 1). In step 2, the desired behaviors and their determinants were established and combined into a matrix comprising 16 change objectives. In step 3 , theoretical methods such as persuasive communication and consciousness-raising were chosen. The program was segmented into three educational activity sessions in step 4 . In step 5, an implementation manual was developed for program instructors to ensure effective and accurate implementation. Finally, practices for evaluating the program's effectiveness and procedures were designed in step 6. Conclusion: The Let's Eat Healthy and Move at School program will provide adolescents with guidelines to promote healthy living and prevent obesity in everyday life using strategies for sustainable adolescent obesity prevention and management.

Key words: Adolescent; Obesity; Program development; School nursing

\section{Corresponding author \\ Gahui Hwang}

College of Nursing, Yonsei University,

50-1 Yonsei-ro, Seodaemun-gu, 03722

Seoul, Korea

TEL: +82-51-890-6079

FAX: $+82-51-896-9840$

E-MAIL: hwang_dawn@naver.com

Received Apr 26, 2021

Revised Jun 7, 2021

Accepted Jul 14, 2021

This is an Open Access article distributed under the terms of the Creative Commons Attribution NonCommercial License (http://creativecommons.org/licenses/by-nc/4.0/) which permits unrestricted noncommercial use, distribution, and reproduction in any medium, provided the original work is properly cited.

\section{INTRODUCTION}

According to the United States Centers for Disease Control and Prevention, the prevalence of obesity in 2017-2018 was $19.3 \%$ among children and adolescents aged 2-19 years old. It was even higher (21.2\%) among adolescents aged $12-19$ years old, particularly compared to children aged 2-5 years (13.4\%) and 6-11 years (20.3\%) [1]. In South Korea, the obesity prevalence among children and adolescents has steadily increased from $8.5 \%$ in 1998 to $10.2 \%$ in 2010 and $11.5 \%$ in 2018 [2]. According to the Korea Youth Risk Behavior Web-based Survey [3], the obesity rate of adolescents was $5.1 \%$ in 2009, $7.5 \%$ in 2016 , and $12.1 \%$ in 2020 . These data provide evidence showing an increase in the obesity rate, which is likely in part due to high academic workloads, needing excessive time to devote to study, and a decrease in physical activity as adoles- cents in Korea move on to higher grade levels [4]. An increase in the rate of overweight and obesity will lead to further health problems for adolescents such as asthma, joint problems, type 2 diabetes, depression, anxiety, and sleep apnea, and can negatively affect academic achievement due to disease-related absences from school [5]. In addition, obese adolescents have a high rate of various psychosocial problems, bullying, bipolar disorder, schizophrenia, and even suicidal thoughts [6]. Neglecting obesity during adolescence will likely lead to obesity in adulthood and comorbidities of obesity-related diseases such as diabetes and hypertension [7].

Adolescent obesity is affected by both individual and environmental factors [4]. The individual factors include excessive academic stress, which can lead to unhealthy eating behaviors and a sedentary lifestyle, such as the development of a gaming or internet addiction [8]. Moreover, physical inactivity al- 
so tends to be high among adolescents who frequently consume fast food [9]. From an environmental point of view, the home environments of adolescents, including being from a low-income household or experiencing poor living conditions, and a lack of opportunities for physical activity at school $[4,10]$ ultimately accelerate the risk of obesity and obesity-related diseases.

Among the various factors that influence adolescent obesity, schools are an important setting within which adolescents can shape obesity-related behaviors [11]. Adolescents spend most of the day at school, and schools offer two meals per day and opportunities for physical activities through physical education classes and break time [11]. Given these circumstances, the United Kingdom has begun to promote various programs at the school level to emphasize healthy living practices. Adolescents who live short distances from their schools are encouraged to walk to school, and students who ride a car to school are encouraged to exit the vehicle at a certain distance from the school and walk the rest of the way for a total of at least 10 minutes [12]. In the United States, administrators installed vending machines that sell healthy foods [13]. Policy-makers in Australia have also undertaken strategies to foster a healthy environment for children and adolescents by implementing school- based programs, among various other strategies, to mitigate the adolescent obesity problem [14]. These examples suggest that many other countries have begun to implement school-based obesity prevention programs with great variety. However, in Korea, few systematic obesity prevention management programs with long-term goals have been developed. In addition, since the school environment in Korea is different from that in other countries, obesity prevention and management programs adapted to the characteristics of the Korean school environment urgently need to be developed. The school environment is vital for the effective prevention and management of adolescent obesity since adolescent obesity involves not only behavioral factors at the individual level, such as poor eating habits and a lack of physical activity to increase energy intake and reduce energy consumption, but also various factors at the environmental level that affect adolescents' physical activity and eating habits $[15,16]$.

Despite the need for adolescent obesity prevention measures, a systematic review on childhood obesity interventions in Korea found that, out of 192 studies from 1996 to 2015, only nine studies (4.7\%) involving adolescents and four $(2.1 \%)$ involving elementary school students and adolescents have been conducted on the topic [17]. In addition, a total of 14 studies (published between 1994 and 2014) that involved adolescent obesity patients were reviewed in research that analyzed the status of adolescent obesity management pro- grams conducted at domestic healthcare institutions [18]. According to this study, eight of the 14 obesity management programs that were implemented were complex programs that combined exercise and education, with nine of the programs having been implemented at general hospitals and five having been conducted at local health centers. While there have been some studies that have targeted adolescents in domestic settings $[19,20]$, these studies have focused on adolescent obesity management rather than obesity prevention. Moreover, there have been no studies emphasizing the role of schools in the daily lives of adolescents concerning obesity prevention, even though schools are where adolescents spend most of their time.

\section{Intervention Mapping}

Intervention mapping (IM) [21] is a widely used protocol for developing tailored interventions using community-based participatory research. Taking an iterative approach, IM offers a structure for systematically developing interventions from problem identification to problem-solving or mitigation (Figure 1). The six steps of IM comprise several tasks, each of which integrates theory and evidence. The completion of the tasks within a step results in the creation of a product that guides the subsequent step. The completion of all of the steps leads to the creation of a blueprint for designing, implementing, and evaluating an intervention based on theoretical, empirical, and practical information. This sequential description of the program components is intended to address the effects of individual and environmental-level determinants, and the behaviors, outcomes, health, and quality of life of the target population [21]. IM has been used as an important method for carrying out various projects worldwide [16] and is expected to be used more extensively in the future.

In conclusion, developing a school-based obesity prevention program for adolescents in Korea is essential, and this study aimed to initiate a systematic process for developing such a program using IM.

\section{METHODS}

Ethics statement: This study was approved by the Institutional Review Board of Inje University (No. INJE 2019-07-027-002).

\section{Research Design}

This paper describes the development of the Let's Eat Healthy and Move at School program for adolescent obesity prevention using the six steps of IM (Figure 1). In step 1 of IM, a needs assessment (or problem analysis) is conducted to iden- 


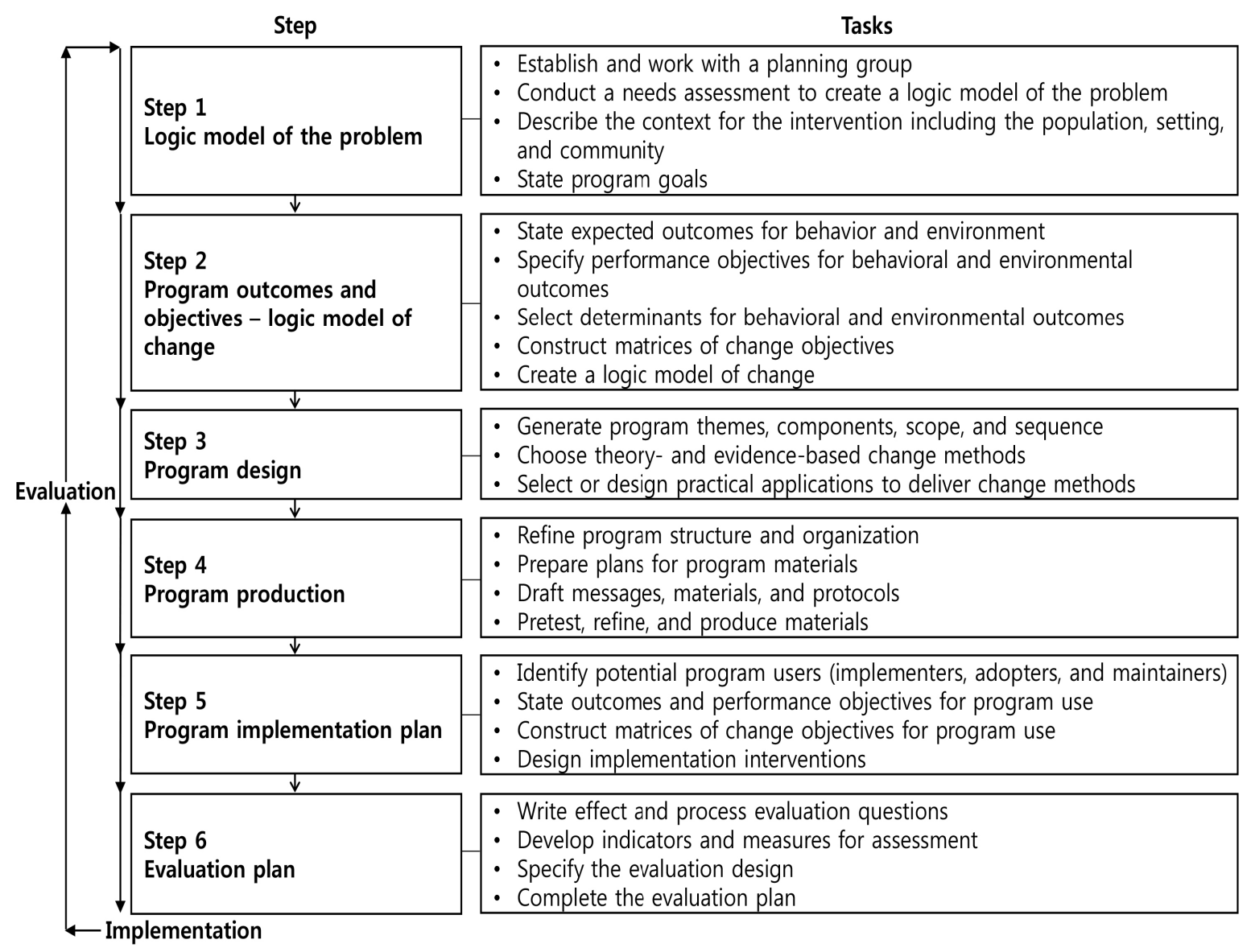

Figure 1. Six steps and tasks of intervention mapping.

tify who the program would target, what needs to change, and for whom. Based on this information a logic model of the problem is created. In step 2 , the program outcomes are identified: a logic model of change is created, and a matrix of change objectives is produced by combining (sub)behaviors with behavioral determinants to identify which beliefs should be targeted by an intervention. Subsequently, in step 3, theory-based methods are chosen that match the determinants into which the identified beliefs are classified. Those methods are translated into practical applications, accounting for the unique conditions (parameters) under which the chosen methods work. In step 4, the program is produced, and in steps 5 and 6, plans are made to optimize opportunities for future implementation and to test the intervention's effectiveness.

\section{1) Step 1: Logic model of the problem}

Step 1 involves organizing a planning group to develop the program and establish a logic model of the problem through a needs assessment. A program planning group includes potential intervention participants, developers, and instructors. Since IM strongly emphasizes the shared values of the stake- holders who participate in the process of program development, the program planning group aims to increase the future practicality and applicability of the program. In addition, focus group interviews and a systematic literature review may be conducted. Outcomes and determinants are identified based on the findings of the needs assessment, and an investigation is carried out as to which types of methods should be used in the program to address the needs and preferences of the target population.

\section{2) Step 2: Program outcomes and objectives - Logic model of change}

Step 2 involves creating a logic model for change and constructing the matrices for developing the program, which is a key part of program development using IM. The matrix consists of performance objectives (POs), individual determinants, and change objectives (COs). Specific POs for achieving the outcomes or goals of the program selected in step 1 are outlined along with the relevant determinants, resulting in the COs that are the focus of the program. 


\section{3) Step 3 and 4: Program design and production}

In Step 3, theory- and evidence-based change methods and practical applications suited to each $\mathrm{CO}$ are selected. According to Bartholomew Eldredge et al. [21] and Kok et al. [22], the use of theory-based methods increases the effectiveness of interventions at changing behavior. They present theory-informed methods for each type of determinant such as awareness or attitude. Practical applications are the means by which the chosen theory-based methods are integrated into an intervention such as lectures or TV advertisements. Then, in step 4, the materials and articles that will be used in the program are created, and, ideally, a preliminary pilot test is conducted with prospective participants.

\section{4) Step 5: Program implementation plan}

Step 5 involves detailed planning concerning the program's implementation to ensure consistency between program instructors and the preparation of strategies to help program implementers with program adoption and use. During this stage, operation manuals to ensure accurate and consistent application of the program by stakeholders are developed.

\section{5) Step 6: Evaluation plan}

During step 6, processes for evaluating the effectiveness and process of the program are developed, and the systematic execution of program evaluation is ensured.

\section{RESULTS}

\section{Step 1: Logic Model of the Problem}

In this study, we designed the planning group to include experts in nursing, medicine, nutrition, health psychology, and program designers. In addition, to conduct the needs assessment, focus group interviews were undertaken that included 15 teachers (4 groups), 4 school nurses (1 group), and 21 obese male and female high school students (3 groups). In addition, an individual interview was conducted with one school nurse. The reason we conducted interviews with overweight or obese adolescents is that understanding their behaviors and environments will ultimately help determine what actions are needed to prevent obesity. The beverages and cookies were provided during the interview to foster an environment in which interviewees felt comfortable talking freely and openly. Interviews lasted approximately 1 hour for each focus group and approximately 30 minutes for individual interviews. The main questions were as follows: "What do you think is the school's role in adolescent obesity prevention and management?" and "What facilitates and inhibits adolescent obesity management and prevention?"
The results of the needs assessment found that the participants agreed about the severity of obesity among high school students. One teacher commented, "Schools are turning students into obese monsters." Students also expressed concerns about the severity of obesity, some of whom said, "I lose weight during school breaks but only gain weight again when I come back to school," and "I gained $10 \mathrm{~kg}$ after entering high school." Participants also sympathized with the need for schools to foster a more healthy environment. Teachers also agreed on the importance of a healthy school environment, with one teacher saying, "We need to create a healthy school environment," and another saying, "The students were definitely slimmer when the school food service was healthy and there wasn't any snack stall in the school." Lastly, a vicious cycle concerning students' individual lifestyles and the school environment was identified: the stress students feel due to excessive academic pressure leads to negative eating habits such as binge eating and night eating as well as unhealthy lifestyle habits such as addictive cell phone use and YouTube obsession. These negative lifestyle habits are accelerated by an unhealthy school environment that promotes poor eating habits and a sedentary lifestyle (e.g. allowing food delivery and replacing physical education time with learning time). Consequently, unhealthy lifestyles related to the school environment directly lead to overweight and obesity. Thus, a step-bystep approach is required to address these problems. Most urgently, students must be able to follow through with their intentions to develop healthy eating habits and participate in physical activities at school.

\section{Step 2: Program Outcomes and Objectives - Logic Model of Change}

In this study, an intervention logic model was constructed for program development directed at the most relevant determinants, based on the theory of planned behavior [22] and the reasoned action approach [23]. Figure 2 shows the logic model of change. The Let's Eat Healthy and Move at School program-a school-based obesity prevention program for adolescents-is expected to improve program participants' awareness, risk perception, skills and self-efficacy, attitude and outcome expectations for obesity prevention, and obesity preventionrelated behaviors (healthy eating and physical activity). These psychosocial determinants are measurable as immediate outcomes. Changes in these psychosocial determinants affect adolescents' intentions to adopt healthy lifestyles (intermediate outcome), which are key for encouraging actual behavioral changes, and ultimately inspire individuals to adopt healthy diets and increase their physical activity (behavioral outcome). 


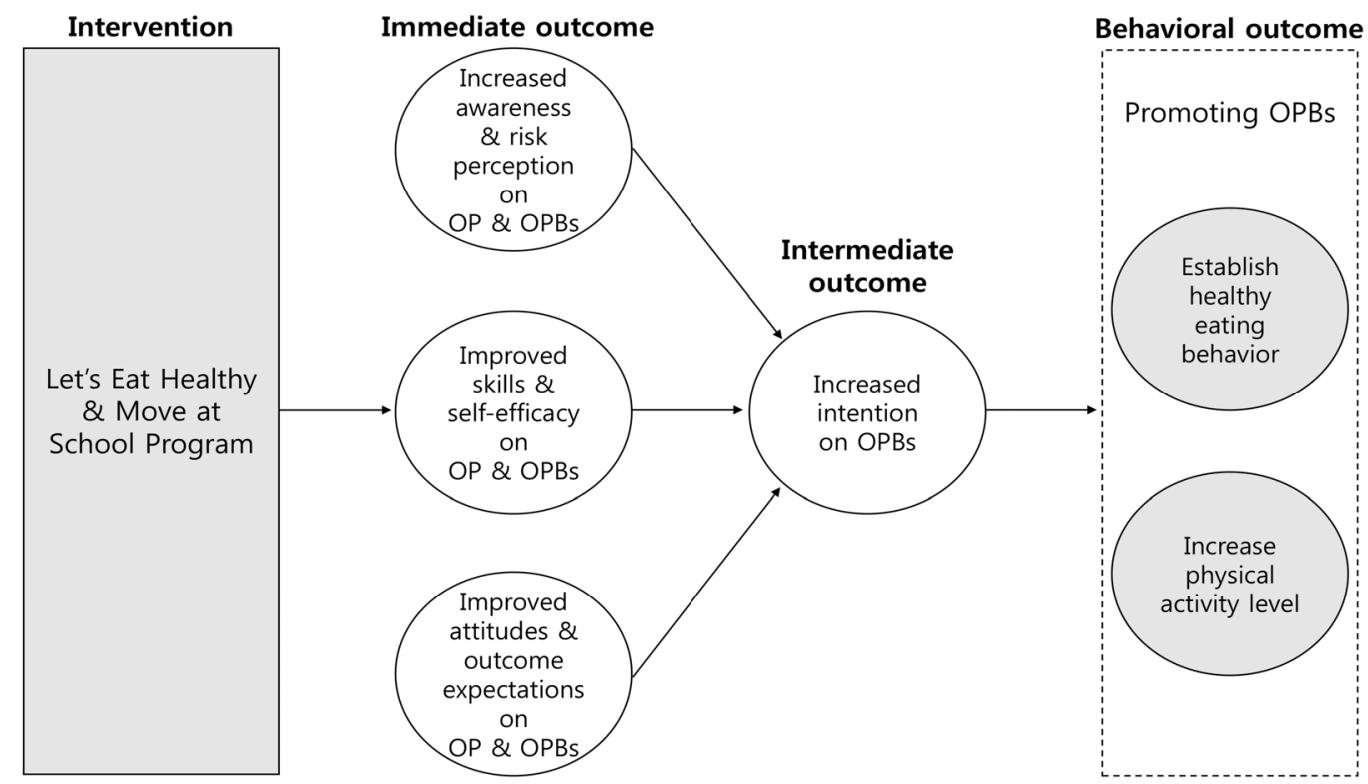

Figure 2. Logic model of change of this study. OP, obesity prevention; OPBs, obesity prevention-related behaviors.

The matrix of this study consists of three POs, six individual determinants, and 16 COs. The three POs are shown in Table 1: 1) find out the why and how of obesity prevention, 2) eat healthy meals and snacks in school, and 3) increase the level of physical activity in school. In addition, six individual determinants, including awareness and risk perception (AR), skills and self-efficacy (SSE), and attitude and outcome expectations (AO) are shown. COs were created at the point where the POs and determinants converged.

\section{Step 3: Program Design}

The theoretical methods used in this study were persuasive communication, raising consciousness, individualization, planning coping responses, feedback, goal setting, and facilitation. The theory-based methods and practical applications applied for each determinant are shown in Table 2. Theoretical methods were assigned to corresponding COs, such as goal setting and feedback, which were applied to COSSE2.3 ("Express confidence that students can eat healthy meals and snacks in school"). Program participants recorded their goals concerning healthy eating at school in a workseet and gave presentations on those goals, for which they received individual feedback. In addition, the theoretical methods of persuasive communication and facilitation were applied to CO SSE3.1 ("List ways to increase the level of physical activity level in schools"). School program instructors provide lectures on how to improve physical activity in school and conduct in-school campaigns such as displaying posters encouraging physical activity and providing students with elastic exercise bands that could be used easily at any time to promote their physical activities.

\section{Step 4: Program Production}

In step 4, the structure and organization of the program were refined, and detailed plans and materials for the program were devised based on the contents designed in step 3 . The program was developed by the four authors by meeting in person several times. In addition, during the design process of the program, the program contents were reviewed in their entirety by two medical doctors who specialized in childhood obesity. The program was designed to comprise three sessions based on the following themes: 1) adolescent obesity and the role of schools, 2) healthy eating behaviors at school, and 3) increasing physical activity at school. The detailed program, along with some of the program materials, is shown in the appendix, which outlines the program and includes information about the length, instructors, place, goals, necessary materials, and the detailed composition of each session.

\section{Step 5: Program Implementation Plan}

In this study, the program instructors were project managers from public health centers or school nurses, since the target population for the program was adolescents in middle 
Table 1. Matrix of Change Objectives for the Let's Eat Healthy and Move at School Program Targeting Students

\begin{tabular}{|c|c|c|c|}
\hline \multirow{2}{*}{ POs } & \multicolumn{3}{|c|}{ COs of individual determinants } \\
\hline & $\mathrm{AR}$ & SSE & $\mathrm{AO}$ \\
\hline \multirow{2}{*}{$\begin{array}{l}\text { PO1. Find out the why and } \\
\text { how of obesity } \\
\text { prevention }\end{array}$} & $\begin{array}{l}\text { 1.1 Understand the need for } \\
\text { obesity prevention }\end{array}$ & 1.1 List ways to prevent obesity & $\begin{array}{l}\text { 1.1 State the advantages of } \\
\text { obesity prevention }\end{array}$ \\
\hline & $\begin{array}{l}\text { 1.2 Understand the need for } \\
\text { obesity prevention in schools }\end{array}$ & & \\
\hline \multirow[t]{3}{*}{$\begin{array}{l}\text { PO2. Eat healthy meals and } \\
\text { snacks in school }\end{array}$} & $\begin{array}{l}\text { 2.1 Acknowledge that there are } \\
\text { barriers to choosing healthy } \\
\text { foods and snacks in school }\end{array}$ & $\begin{array}{l}\text { 2.1 List ways to eat healthy meals } \\
\text { and snacks in school }\end{array}$ & $\begin{array}{l}\text { 2.1 State the advantages of } \\
\text { eating breakfast }\end{array}$ \\
\hline & $\begin{array}{l}\text { 2.2 Acknowledge that there are } \\
\text { barriers to eating meals on } \\
\text { time }\end{array}$ & $\begin{array}{l}\text { 2.2 List possible solutions to } \\
\text { overcome barriers }\end{array}$ & \\
\hline & $\begin{array}{l}\text { 2.3 Acknowledge that there are } \\
\text { barriers to eating the right } \\
\text { portion size during meals }\end{array}$ & $\begin{array}{l}2.3 \text { Express confidence that } \\
\text { students can eat healthy meals } \\
\text { and snacks in school }\end{array}$ & \\
\hline \multirow[t]{3}{*}{$\begin{array}{l}\text { PO3. Increase the level of } \\
\text { physical activity in } \\
\text { school }\end{array}$} & \multirow{3}{*}{$\begin{array}{l}\text { 3.1 Acknowledge that there are } \\
\text { barriers when increasing the } \\
\text { level of physical activity in } \\
\text { schools }\end{array}$} & $\begin{array}{l}\text { 3.1 List ways to increase the level } \\
\text { of physical activity level in } \\
\text { schools }\end{array}$ & $\begin{array}{l}\text { 3.1 State the advantages of } \\
\text { physical activity }\end{array}$ \\
\hline & & $\begin{array}{l}\text { 3.2 List possible solutions to } \\
\text { overcome barriers }\end{array}$ & \\
\hline & & $\begin{array}{l}\text { 3.3 Express confidence that } \\
\text { students can increase their } \\
\text { level of physical activity in } \\
\text { school }\end{array}$ & \\
\hline
\end{tabular}

$\mathrm{AO}$, attitudes and outcome expectations; $\mathrm{AR}$, awareness and risk perception; $\mathrm{CO}$, change objective; $\mathrm{PO}$, performance objective; SSE, skills and self-efficacy.

and high schools. We developed a program implementation manual so that the program instructors could systematically and easily implement the program in schools. The implementation manual gives an outline of the program and presents in concrete detail the goals, necessary materials, composition and special notes, procedures for each session, and methods for taking body measurements.

\section{Step 6: Evaluation Plan}

A self-report questionnaire survey to be conducted before and after program implementation was designed to evaluate the program's effectiveness. The Obesity Prevention-related Behaviors Intention Questionnaire-a survey instrument for measuring the immediate and intermediate outcomes in the logic model of change (Figure 2)-was developed based on the program matrix (Table 1) using the method suggested by Fishbein and Ajzen [23]. They outlined how to construct questionnaire items based on each determinant and suggested a 7-point Likert scale for rating them. The instrument in this study was designed to consist of 11 items to measure the psychosocial determinants of obesity prevention behaviors in adolescents, including their awareness and risk perception $(4$ items), skills and self-efficacy ( 2 items), attitudes and outcome expectations ( 3 items), and intentions ( 2 items) (Table 3 ). The contents of these items were reviewed by one health psychology expert and two medical doctors who specialized in childhood obesity. Each item was designed to be rated on a 7-point Likert scale with possible scores ranging from 11 to 77 points, with a higher score indicating a greater intention to adopt behaviors to prevent obesity. In addition, the behavioral outcomes in the logic model of change (Figure 2) were measured using the Nutrition Quotient for Adolescents [24] and Korean Youth Physical Activity Questionnaire [25].

A post-participation satisfaction survey designed to be completed by program participants was developed for evaluating the program process. The program satisfaction survey comprised nine questions to evaluate participants' satisfaction concerning the program's contents and operation, as well as their willingness to participate in the program again, and included a blank section where participants could answer in their own words what they felt and thought about the program. Each item was designed to be measured on a 5-point Likert scale, with total possible scores ranging from 9 to 45 points and a 
Table 2. Theoretical Methods and Practical Applications Related to the Let's Eat Healthy and Move at School Program

\begin{tabular}{|c|c|c|c|}
\hline COs & Theoretical methods*: Definition & Parameters for effectiveness & Practical applications \\
\hline \multicolumn{4}{|l|}{ Awareness and risk perception } \\
\hline $\begin{array}{l}\text { 1.1 Understand the need for } \\
\text { obesity prevention }\end{array}$ & $\begin{array}{l}\text { Persuasive communication } \\
\text { (communication-persuasion } \\
\text { matrix [26]; elaboration } \\
\text { likelihood model [27]; } \\
\text { diffusion of innovations } \\
\text { theory [28]): Guiding } \\
\text { individuals and } \\
\text { environmental agents toward } \\
\text { the adoption of an idea, } \\
\text { attitude, or action by using } \\
\text { arguments or other means }\end{array}$ & $\begin{array}{l}\text { Messages need to be relevant } \\
\text { and not too divergent from } \\
\text { the beliefs of the individual; } \\
\text { can be stimulated by surprise } \\
\text { and repetition. Will include } \\
\text { arguments }\end{array}$ & $\begin{array}{l}\text { Collective education (lecture) } \\
\text { - Summarize the present-day state of } \\
\text { adolescent obesity and the important } \\
\text { role of schools in obesity prevention } \\
\text { - Instructors repeatedly emphasize the } \\
\text { importance of obesity prevention and } \\
\text { adolescents' lives in school during } \\
\text { lecture } \\
\text { - Lecture materials (PPTX) are used }\end{array}$ \\
\hline $\begin{array}{l}\text { 1.2 Understand the need for } \\
\text { obesity prevention in } \\
\text { schools }\end{array}$ & $\begin{array}{l}\text { Consciousness-raising (health } \\
\text { belief model [29]; } \\
\text { precaution-adoption process } \\
\text { model [30]; trans-theoretical } \\
\text { model [31]): Providing } \\
\text { information, feedback, or } \\
\text { confrontation about the } \\
\text { causes, consequences, and } \\
\text { alternatives for a problem or } \\
\text { a problem behavior }\end{array}$ & $\begin{array}{l}\text { Can use feedback and } \\
\text { confrontation; however, } \\
\text { raising awareness should be } \\
\text { quickly followed by } \\
\text { increases in problem-solving } \\
\text { ability and (collective) } \\
\text { self-efficacy }\end{array}$ & $\begin{array}{l}\text { Height measurement; weight } \\
\text { measurement; worksheet activity; } \\
\text { collective education (lecture) } \\
\text { - Heights and weights of individual } \\
\text { students are measured, recorded in } \\
\text { worksheets, and given to the } \\
\text { corresponding student } \\
\text { - Each student conducts a self-evaluation } \\
\text { of his/her obesity level to understand } \\
\text { his/her condition } \\
\text { - Summarize the causes of, consequences } \\
\text { of, and solutions to adolescent obesity }\end{array}$ \\
\hline $\begin{array}{l}\text { 2.1 Acknowledge that there } \\
\text { are barriers to choosing } \\
\text { healthy foods and } \\
\text { snacks in school } \\
\text { 2.2 Acknowledge that there } \\
\text { are barriers to eating } \\
\text { meals on time }\end{array}$ & $\begin{array}{l}\text { Individualization } \\
\text { (trans-theoretical model } \\
\text { [32-34]): Providing } \\
\text { opportunities for learners to } \\
\text { have personal questions } \\
\text { answered or instructions } \\
\text { paced according to their } \\
\text { individual prooress }\end{array}$ & $\begin{array}{l}\text { Personal communication that } \\
\text { responds to a learner's needs }\end{array}$ & $\begin{array}{l}\text { Worksheet activity } \\
\text { - Each student records in his/her } \\
\text { worksheet their experiences related to } \\
\text { healthy eating and their reasons for not } \\
\text { eating healthy meals and snacks and } \\
\text { not practicing physical activities in } \\
\text { school }\end{array}$ \\
\hline
\end{tabular}

2.3 Acknowledge that there are barriers to eating the right portion size during meals

individual progress

3.1 Acknowledge that there are barriers when increasing the level of physical activity in schools

\section{Skills and self-efficacy}

1.1 List ways to prevent obesity

2.1 List ways to eat healthy meals and snacks in school
Persuasive communication (communication-persuasion matrix [26]; elaboration likelihood model [27]; diffusion of innovations theory [28]): guiding individuals and environmental agents toward the adoption of an idea, attitude, or action by using arguments or other means

Persuasive communication (communication-persuasion matrix [26]; elaboration likelihood model [27]; diffusion of innovations theory [28]): Guiding individuals and environmental agents toward the adoption of an idea, attitude, or action by using arguments or other means
Messages need to be relevant and not too divergent from the beliefs of the individual; can be stimulated by surprise and repetition. Will include arguments
Collective education (lecture)

- Introduce ways to prevent obesity (practice healthy eating habits and improve physical activities)

- Instructors repeat obesity prevention methods when ending lecture

- Lecture materials (PPTX) are used
Messages need to be relevant and not too divergent from the beliefs of the individual; can be stimulated by surprise and repetition. Will include arguments
Collective education (lecture)

- Introduce ways to practice healthy eating habits at school

- Instructors repeat how to choose healthy foods when ending the lecture

- Lecture materials (PPTX) are used

\footnotetext{
*The theoretical method is introduced in a book by Bartholomew Eldredge et al. [21] (page 376-398); COs, change objectives; PPTX, PowerPoint file.
} 
Table 2. Theoretical Methods and Practical Applications Related to the Let's Eat Healthy and Move at School Program (Continued)

COs Theoretical methods*: Definition Parameters for effectiveness Practical applications

\section{Skills and self-efficacy}

2.2 List possible solutions to overcome barriers

2.3 Express confidence that students can eat healthy meals and snacks in school

3.1 List ways to increase the level of physical activity level in school
Planning coping responses (attribution theory and relapse prevention theory [35]; theories of goal-directed behavior [36]): Getting the person to identify potential barriers and ways to overcome these

Feedback (theories of learning [37]; goal setting theory [38]; social cognitive theory [39]):

Giving information to individuals and

environmental agents regarding the extent to which they are accomplishing learning or performance, or the extent to which performance is having an impact

Goal-setting (goal setting theory; theories of self-regulation [39]): Prompting planning what the person will do, including a definition of goal-directed behaviors that result in the target behavior

Feedback (theories of learning [37]; goal setting theory [38]; social cognitive theory [39]):

Giving information to individuals and

environmental agents regarding the extent to which they are accomplishing learning or performance, or the extent to which performance is having an impact

Persuasive communication (communication-persuasion matrix [26]; elaboration likelihood model [27]; diffusion of innovations theory [28]): Guiding individuals and environmental agents toward the adoption of an idea, attitude, or action by using arguments or other means

Facilitation (social cognitive theory [40]): Creating an environment that makes the action easier or reduces barriers to action
Identification of high-risk situations and practicing coping responses individual, address behaviors in real-time, and be specific
Worksheet activity

- Students record in their worksheets the barriers to practicing healthy eating habits at school and how to overcome them

Presentation

- Provide feedback after each student's presentation on his/her personal experience
Commitment to the goal; goals that are difficult but achievable within individuals' skill levels

Feedback needs to be individual, address behaviors in real-time, and be specific
Worksheet activity

- Each student records in his/her worksheet their goals for practicing healthy eating habits at school

Presentation

- Provide feedback after each student's presentation on their goals for practicing healthy eating habits at school
Messages need to be relevant and not too divergent from the beliefs of the individual; can be stimulated by surprise and repetition. Will include arguments
Requires real changes in one's environment instead of just one's perception of the environment. Requires identification of barriers and facilitators and the power for making appropriate changes. Facilitating conditions on one environmental level are usually dealt with by intervening on a higher environmental level
Collective education (lecture); in-school campaign (poster display)

- Introduce ways to improve physical activities at school

- Instructors repeat ways to improve physical activities at the end of the lecture

- Lecture materials (PPTX) and posters are used

Resistance band

- Provide resistance bands for students that can be used easily at school and teach exercise methods that use the band

\footnotetext{
*The theoretical method is introduced in a book by Bartholomew Eldredge et al. [21] (page 376-398); COs, change objectives; PPTX, PowerPoint file.
} 
Table 2. Theoretical Methods and Practical Applications Related to the Let's Eat Healthy and Move at School Program (Continued)

COs Theoretical methods*: Definition Parameters for effectiveness Practical applications

\section{Skills and self-efficacy}

3.2 List possible solutions to overcome barriers

3.3 Express confidence that students can increase their level of physical activity in school
Planning coping responses (attribution theory and relapse prevention theory [35]; theories of goal-directed behavior [36]): Getting the person to identify potential barriers and ways to overcome these

Feedback (theories of learning [37]; goal setting theory [38]; social cognitive theory [39]): Giving information to individuals and environmental agents regarding the extent to which they are accomplishing learning or performance, or the extent to which performance is having an impact

Goal-setting (goal setting theory; theories of self-regulation [39]) Prompting planning what the person will do, including a definition of goal-directed behaviors that result in the target behavior

Feedback (theories of learning [37]; goal setting theory [38]; social cognitive theory [39]):

Giving information to individuals and environmental agents regarding the extent to which they are accomplishing learning or performance, or the extent to which performance is having an impact

\section{Attitudes and outcome expectations}

1.1 State the advantages of obesity prevention

2.1 State the advantages of eating breakfast

3.1 State the advantages of physical activity
Persuasive communication (communication-persuasion matrix [26]; elaboration likelihood model [27]; diffusion of innovations theory [28]): Guiding individuals and environmental agents toward the adoption of an idea, attitude, or action by using arguments or other means

Persuasive communication (communication-persuasion matrix [26]; elaboration likelihood model [27]; diffusion of innovations theory [28]): Guiding individuals and environmental agents toward the adoption of an idea, attitude, or action by using arguments or other means

Persuasive communication (communication-persuasion matrix [26]; elaboration likelihood model [27]; diffusion of innovations theory [28]): Guiding individuals and environmental agents toward the adoption of an idea, attitude, or action by using arguments or other means
Identification of high-risk situations and practicing coping responses

Worksheet activity

- Students record in their worksheets barriers to improving their physical activity at school and how to overcome them

Feedback needs to be individual, address behaviors in real-time, and be specific
Presentation

- Provide feedback after each student's presentation on his/her personal experience
Commitment to the goal; goals that are difficult but achievable within individuals' skill levels

Feedback needs to be individual, address behaviors in real-time, and be specific
Worksheet activity

- Each student records in his/her worksheet goals for improving physical activities at school at the end of education

Presentation

- Provide feedback after each student's presentation on their goals for improving their physical activity at school
Messages need to be relevant and not too divergent from the beliefs of the individual; can be stimulated by surprise and repetition. Will include arguments
Collective education (lecture)

- Summarize the advantages of obesity prevention

- Instructors repeat the advantages of obesity prevention at the end of the lecture

- Lecture materials (PPTX) are used
Messages need to be relevant and not too divergent from the beliefs of the individual; can be stimulated by surprise and repetition. Will include arguments
Collective education (lecture)

- Summarize the advantages of eating breakfast

- Instructors repeat the advantages of eating breakfast at the end of the lecture

- Lecture materials (PPTX) are used
Messages need to be relevant and not too divergent from the beliefs of the individual; can be stimulated by surprise and repetition. Will include arguments
Collective education (lecture)

- Summarize the advantages of physical activity

- Instructors repeat the advantages of physical activity at the end of the lecture

- Lecture materials (PPTX) are used

${ }^{\star}$ The theoretical method is introduced in a book by Bartholomew Eldredge et al. [21] (page 376-398); COs, change objectives; PPTX, PowerPoint file. 
Table 3. Questionnaire Items Based on the Program Matrix in Step 2

\begin{tabular}{|c|c|c|c|c|c|}
\hline Individual determinants & \multicolumn{5}{|c|}{ Answer } \\
\hline \multicolumn{6}{|l|}{ Awareness and risk perception } \\
\hline $\begin{array}{l}\text { AR1.1 Understand the need for obesity prevention } \\
\text { - Healthy eating is necessary to maintain a healthy weight and prevent chronic disease } \\
\text { - Physical activity is necessary to maintain a healthy weight and prevent chronic disease }\end{array}$ & Agree & \multicolumn{3}{|c|}{ - Healthy eating is necessary to maintain a healthy weight and prevent chronic disease } & sagree \\
\hline $\begin{array}{l}\text { AR1.2 Understand the need for obesity prevention in schools } \\
\text { - A healthy school environment is necessary to prevent obesity } \\
\text { - Healthy eating and physical activity at school is necessary to prevent obesity }\end{array}$ & 76 & 5 & 4 & 3 & \\
\hline \multicolumn{6}{|l|}{ Skills and self-efficacy } \\
\hline \multicolumn{6}{|l|}{ SSE2.3 Express confidence that students can eat healthy meals and snacks in school } \\
\hline $\begin{array}{l}\text { SSE3.3 Express confidence that students can increase their level of physical activity in school } \\
\text { - I'm confident that I can increase my physical activity level at school }\end{array}$ & 76 & 5 & 4 & 3 & 21 \\
\hline
\end{tabular}

Attitudes and outcome expectations

AO1.1 State the advantages of obesity prevention

- Eating healthy meals and snacks at school would help prevent obesity

AO2.1 State the advantages of eating breakfast

- Eating breakfast would help to prevent obesity

Pleasant Unpleasant

$\begin{array}{lllllll}7 & 6 & 5 & 4 & 3 & 2 & 1\end{array}$

AO3.1 State the advantages of physical activity

- Increasing my level of physical activity at school would help prevent obesity

Intention

- I intend to eat healthy meals and snacks at school

- I intend to increase my physical activity level at school

Likely Unlikely

$\begin{array}{lllllll}7 & 6 & 5 & 4 & 3 & 2 & 1\end{array}$

$\mathrm{AO}$, attitudes and outcome expectations; AR, awareness and risk perception; SSE, skills and self-efficacy.

higher total score indicating greater satisfaction with the program.

\section{DISCUSSION}

The Let's Eat Healthy and Move at School program was developed using the six steps of IM, an advanced health planning methodology. In this study, the entire session was organized in accordance with the six steps of IM, and the objectives, interventions, and scope of each session were specified. The program planning team was organized with the input of multidisciplinary experts. In step 1, the problems and actual conditions of adolescent obesity were identified based on in-depth interviews with various stakeholders on the topic of adolescent obesity. In step 2, findings from the needs assessment were translated into a matrix of COs. In step 3 , suitable theoretical methods and applications were matched to the COs established in the previous step. The program was designed and organized in step 4, and an operation manual was developed for prospective program instructors in step 5 . Lastly, methods to evaluate the program's effectiveness and process were devised in step 6. These steps resulted in the creation of a program comprising three in-school sessions that include educational activities and an in-school campaign to prevent adolescent obesity through the adoption of healthy eating habits and the promotion of physical activities at school.

IM is a planning framework that provides a systematic process and detailed protocol for effective step-by-step decisionmaking in the development, implementation, and evaluation of interventions. It is actively used around the world for developing various health promotion programs for children and adolescents [41]. For example, a community-oriented obesity prevention program for children aged 2-9 years was developed, implemented, and evaluated across eight European countries (Sweden, Germany, Hungary, Italy, Cyprus, Spain, Belgium, and Estonia) as part of the Identification and Prevention of Dietary- and Lifestyle-induced Health Effects in Children and Infants (IDEFICS) longitudinal study [42], which was conducted from September 2006 to February 2012 and led to the ratification of the IDEFICS Charter. The IDEFICS was formally launched in Sweden in May 2011 and has since been consulted by various local communities, politicians, and poli- 
cy legislators interested in preventing childhood obesity for its evidence-based guidelines [42]. In the Netherlands, a protocol for a school-based program aimed at improving the quality of life of overweight adolescents by promoting physical activity was developed and conducted in 2016 [16], and an obesity prevention intervention program was developed in 2019 for children aged 9-12 years who reside in low-socioeconomic status areas to improve their health behaviors [10]. Thus, IM has been actively used for developing and evaluating health promotion programs in many countries.

In contrast, there have been few domestic studies to systematically apply IM in Korea. One of the few Korean studies to use IM was Hwang's 2021 study [43] on the development and effectiveness of a program to promote the obesity prevention behaviors of preschool children [21]. In Hwang's study [43], a program was developed to improve the eating habits, physical activities, and sedentary behaviors of preschool children. The program consisted of eight sessions across four weeks, was designed using IM, and used various intervention strategies (e.g., lectures, activities, and practice). As already mentioned, IM provides a systematic process for changing the behaviors of participants and has the advantage of being widely applicable for programs targeting various groups (e.g., children, adolescents, and parents) and environments (e.g., schools and community organizations). In this respect, the present study is significant in that it used IM to systematically develop an obesity prevention program aimed at changing adolescents' behaviors (healthy eating habits and physical activities). It is expected that IM will continue to be actively used for developing theory- and evidence-based programs in the area of child health promotion.

In order to effectively prevent and manage obesity in adolescents, it is necessary to reinforce a healthy lifestyle in schools and foster a healthy school environment in addition to providing support to individual students. Schools are especially important for the prevention and management of adolescent obesity, particularly in Korea, since Korean students are highly prone to obesity due to a significant cultural emphasis on schoolwork, widespread unhealthy eating habits and sedentary lifestyles, and long school hours compared to students in other countries $[4,8]$. The recent surge in the adolescent obesity rate further indicates an urgent need for interventions. Various efforts have been made internationally to foster healthy school environments, such as installing vending machines with healthy snack options [13] and encouraging students to walk to school to increase their physical activity [12]. Finland, in particular, was able to reduce the obesity rate among Finnish children from $16.1 \%$ to $8.2 \%$ in just 3 years by implementing a national action program called "Schools on the Move" [44]. Thus, interventions and strategies must be im- plemented with urgency in Korea to reduce the rapidly increasing adolescent obesity rate. In conclusion, this study is significant since it is the first to apply the IM health planning methodology to the development of an adolescent health promotion program in Korea, and since it encourages students to independently practice healthy eating habits and participate in physical activities in schools, where adolescents spend the most time.

Nevertheless, the program developed in this study has some limitations. First, according to the ecological model of McLeroy et al. [45], behavioral changes in individuals are much more effective when they coincide with changes in the environment. The program in this study primarily focuses on individual changes in obesity prevention behaviors and should be modified and supplemented in the future with programs that incorporate changes in the actual environments that surround adolescents (e.g. parents, teachers, and the school environment). Second, the program was developed as a short-term program comprising three sessions due to constraints in the research conditions such as a limited development period and budget. Therefore, long-term programs are also needed to ensure more active, long-term behavioral changes in adolescents. In particular, programs that take into account the preferences of adolescents, such as apps, mobile-based elements, and social media services, in their practical applications are needed. Moreover, the program should be supplemented with different elements according to the degree of obesity among the target population (obese, overweight, and normal-weight groups, as well as underweight groups). Third, in this study, we developed a matrix according to the methods proposed by Fishbein and Ajzen [23], upon which the development of our tool was based. Therefore, the reliability and validity of the tools still need to be tested in the future. Lastly, changes in adolescents' health behaviors, health problems, and quality of life, as well as changes in the school environment resulting from the program, need to be longitudinally evaluated.

\section{CONCLUSION}

In this study, the Let's Eat Healthy and Move at School program was developed according to the six steps of IM, an advanced and widely used health promotion planning protocol. This study is meaningful in that an adolescent obesity prevention program was systematically developed by following all six steps of IM, which reflects the needs of schools, thus increasing the program's practical utility. Preliminary evaluation of the program developed in this study will provide multi-dimensional verification of its applicability in the school setting. In addition, a plan to link programs between public 
health centers and schools should be devised to revitalize youth obesity prevention programs. The program developed in this study will be a significant contribution to adolescent obesity prevention.

\section{ORCID}

Jiyoung Park

Gill A. Ten Hoor

Seolhyang Baek

Sochung Chung

Yang-Hyun Kim

Gahui Hwang https://orcid.org/0000-0003-1374-9187

https://orcid.org/0000-0001-5500-1893

https://orcid.org/0000-0001-9934-2884

https://orcid.org/0000-0002-7655-2691

https://orcid.org/0000-0003-3548-8758

https://orcid.org/0000-0002-4298-5763

\section{Authors' contribution}

Conceptualization: Jiyoung Park, Gahui Hwang; Data collection: Jiyoung Park, Gahui Hwang; Formal analysis: all authors; Writing- original draft, Writing-review and editing: all authors; Final approval of published version: all authors.

\section{Conflict of interest}

No existing or potential conflict of interest relevant to this article was reported.

\section{Funding}

This work was supported by policy research project grant funded by the Korea Health Promotion Institute.

\section{Data availability}

Please contact the corresponding author for data availability.

\section{Acknowledgements}

None.

\section{REFERENCES}

1. Centers for Disease Control and Prevention. Childhood obesity facts [Internet]. Atlanta, GA: Centers for Disease Control and Prevention; 2021 [cited 2021 January 3]. Available from: https://www.cdc.gov/obesity/data/childhood.html

2. Korea Disease Control and Prevention Agency. Chronic disease health statistics 2018 [Internet]. Cheongju: Korea Disease Control and Prevention Agency; 2018 [cited 2020 December 13]. Available from:

https://health.cdc.go.kr/healthinfo/biz/pblcVis/details.do?ctgr
$\mathrm{Sn}=31$

3. Korea Disease Control and Prevention Agency. Korea youth risk behavior web-based survey [Internet]. Cheongju: Korea Disease Control and Prevention Agency; 2021 [cited 2021 March 5]. Available from: http://www.kdca.go.kr/yhs/

4. Park SY. A multilevel model analysis of factors associated with adolescent obesity. Health and Social Welfare Review. 2019;39(3): 314-347. https://doi.org/10.15709/hswr.2019.39.3.314

5. Action for Healthy Kids. The learning connection: The value of improving nutrition and physical activity in our schools [Internet]. Chicago, IL: Action for Healthy Kids; 2004 [cited 2021 Feburary 17]. Available from:

https://www.actionforhealthykids.org/the-learning-connection/

6. van Vuuren CL, Wachter GG, Veenstra R, Rijnhart JJ, van der Wal MF, Chinapaw MJ, et al. Associations between overweight and mental health problems among adolescents, and the mediating role of victimization. BMC Public Health. 2019;19(1):612. https://doi.org/10.1186/s12889-019-6832-z

7. Freedman DS, Dietz WH, Srinivasan SR, Berenson GS. The relation of overweight to cardiovascular risk factors among children and adolescents: The Bogalusa heart study. Pediatrics. 1999;103(6): 1175-1182. https://doi.org/10.1542/peds.103.6.1175

8. Park MH, Song HY. Relationship among the Korean adolescents obesity, health behavior and smart phone usage. Journal of Korean Public Health Nursing. 2019;33(1):47-58.

https://doi.org/10.5932/JKPHN.2019.33.1.47

9. Boutelle KN, Fulkerson JA, Neumark-Sztainer D, Story M, French SA. Fast food for family meals: Relationships with parent and adolescent food intake, home food availability and weight status. Public Health Nutrition. 2007;10(1):16-23. https://doi.org/10.1017/S136898000721794X

10. Anselma M, Altenburg TM, Emke H, van Nassau F, Jurg M, Ruiter RA, et al. Co-designing obesity prevention interventions together with children: Intervention mapping meets youth-led participatory action research. International Journal of Behavioral Nutrition and Physsical Activity. 2019;16(1):130. https://doi.org/10.1186/s12966-019-0891-5

11. Ten Hoor GA, Plasqui G, Schols AM, Kok G. Development, implementation, and evaluation of an interdisciplinary theory- and evidence-based intervention to prevent childhood obesity: Theoretical and methodological lessons learned. Frontiers in Public Health. 2017;5:352. https://doi.org/10.3389/fpubh.2017.00352

12. European Commission. EU action plan on childhood obesity 20142020 [Internet]. Brussels: European Commission; 2014 [cited 2021 March 5].Available from: https://ec.europa.eu/health/sites/health/files/nutrition_physical _activity/docs/childhoodobesity_actionplan_2014_2020_en.pdf

13. Centers for Disease Control and Prevention. Characteristics of vending machines available to Students in U.S. schools: Results from the school health policies and practices study [Internet]. 
Atlanta, GA: Department of Health and Human Services; 2014 [cited2021 March 7]. Available from:

https://www.cdc.gov/healthyschools/nutrition/pdf/18_296717 -A_VendingMachBk_Final2_508.pdf

14. Bauman A, Bellew B, Boylan S, Crane M, Foley B, Gill T, et al. Obesity prevention in children and young people aged 0-18 years: A rapid evidence review. Full Technical Report. Sydney: The University of Sydney; 2016.

15. Nathan N, Janssen L, Sutherland R, Hodder RK, Evans CE, et al. The effectiveness of lunchbox interventions on improving the foods and beverages packed and consumed by children at centre-based care or school: A systematic review and meta-analysis. International Journal of Behavioral Nutrition and Physical Activity. 2019;16(1):38. https://doi.org/10.1186/s12966-019-0798-1

16. Ten Hoor GA, Kok G, Rutten GM, Ruiter RA, Kremers SP, Schols $\mathrm{AM}$, et al. The dutch 'Focus on Strength' intervention study protocol: Programme design and production, implementation and evaluation plan. BMC Public Health. 2016;16:496.

https://doi.org/10.1186/s12889-016-3150-6

17. Park J, Ma H, Lee YN, Oh H. Trends in intervention study for childhood obesity in Korea. Child Health Nursing Research. 2017;23(1): 81-90. https://doi.org/10.4094/chnr.2017.23.1.81

18. Go DS, Choi M, Hong SW, Lee SH, Kim YE, Noh JW. Evaluation of healthcare organization based management program in Korea: Using chronic care model. Korean Journal of Hospital Management. 2016;21(1):14-31.

19. Oh NH. A meta-analysis on the effects of combined exercise program on body composition and blood lipid of obese adolescents [dissertation]. Seoul: Sungshin University; 2019. p. 1-119.

20. Kim YH, Kim HS, Kang SJ. Effects of obesity management program on changes in body mass, physical activity and its related psychological variables in obese adolescents. Korean Journal of Sport and Exercise Psychology. 2013;24(1):193-208.

21. Bartholomew Eldrigde LK, Markham CM, Ruiter RA, Fernàndez ME, Kok G, Parcel GS. Planning health promotion programs: An intervention mapping approach. 4th ed. San Francisco, CA: JosseyBass; 2016. p. 3-649.

22. Kok G, Gottlieb NH, Peters GJ, Mullen PD, Parcel GS, Ruiter RA, et al. A taxonomy of behaviour change methods: An intervention mapping approach. Health Psychology Review. 2016;10(3):297-312. https://doi.org/10.1080/17437199.2015.1077155

23. Fishbein M, Ajzen I. Predicting and changing behavior: The reasoned action approach. New York, NY: Psychology Press; 2010. p. 3-21.

24. Kim HY, Lee JS, Hwang JY, Kwon S, Chung HR, Kwak TK, et al. Development of NQ-A, nutrition quotient for Korean adolescents, to assess dietary quality and food behavior. Journal of Nutrition and Health. 2017;50(2):142-157.

https://doi.org/10.4163/jnh.2017.50.2.142

25. Hong SY, Yang YJ, Park HK, Kim BS. Validation of Korean youth physical activity questionnaire (KYPAQ). Korean Journal of Physical Education. 2006;45(5):161-173.

26. McGuire WJ. Input and output variables currently promising for constructing persuasive communications. In: Rice RE, Atkin CK, editors. Public communication campaigns. 3rd ed. Thousand Oaks, CA: Sage; 2001. p. 22-48.

27. Petty RE, Barden J, Wheeler SC. The Elaboration Likelihood Model of persuasion: Developing health promotions for sustained behavioral change. In: DiClemente RJ, Crosby RA, Egler MC, editors. Emerging theories in health promotion practice and research. 2nd ed. San Francisco, CA: Jossey-Bass; 2009. p. 185-241.

28. Rogers EM. Diffusion of innovations. 5th ed. Washington D.C.: Free Press; 2003.

29. Skinner CS, Tiro J, Champion VL. The health belief model. In: Glanz K, Rimer KK, Viswanath K, editors. Health behavior and health education: Theory, research, and practice. 5th ed. San Francisco, CA: Jossey-Bass; 2015. p. 131-167.

30. Prochaska JO, Redding CA, Evers KE. The transtheoretical model of stages of change. In: Glanz K, Rimer KK, Viswanath K, editors. Health behavior and health education: Theory, research, and practice. 5th ed. San Francisco, CA: Jossey-Bass; 2015. p. 168-222.

31. Weinstein ND, Sandman PM, Blalock SJ. The precaution adoption process model. In: Glanz K, Rimer BK,Viswanath K, editors. Health behavior and health education: Theory, research, and practice. 4th ed. San Francisco, CA: Jossey-Bass; 2008. p. 123-165.

32. Bartholomew LK, Czyzewski DI, Swank PR, McCormick L, Parcel GS. Maximizing the impact of the cystic fibrosis family education program: Factors related to program diffusion. Family and Community Health. 2000;22(4):27-47.

https://doi.org/10.1097/00003727-200001000-00005

33. Bartholomew LK, Gold RS, Parcel GS, Czyzewski DI, Sockrider MM, Fernández M, et al. Watch, discover, think, and act: Evaluation of computer assisted instruction to improve asthma self-management in inner-city children. Patient Education and Counseling. 2000;39(2-3):269-280.

https://doi.org/10.1016/s0738-3991(99)00046-4

34. Prochaska JO, Redding CA, Evers KE. The transtheoretical model of stages of change. In: Glanz K, Rimer KK, Viswanath K, editors. Health behavior and health education: Theory, research, and practice. 5th ed. San Francisco, CA: Jossey-Bass; 2015. p. 168-222.

35. Hofmann W, Friese M, Wiers RW. Impulsive versus reflective influences on health behavior: A theoretical framework and empirical review. Health Psychology Review. 2008;2(2):111-137. https://doi.org/10.1080/17437190802617668

36. Marlatt GA, Donovan DM. Relapse prevention: Maintenance strategies in the treatment of addictive behaviors. 2nd ed. New York, NY: Guilford Press; 2005.

37. Kazdin AE. Behavior modification in applied settings. 7th ed. Long Grove, IL: Waveland Press; 2012.

38. Kelder S, Hoelscher D, Perry CL. How individuals, environments, 
and health behaviour interact: Social Cognitive Theory. In: Glanz K, Rimer KK, Viswanath K, editors. Health behavior and health education: Theory, research, and practice. 5th ed. San Francisco, CA: Jossey-Bass; 2015. p. 285-325.

39. Latham GP, Locke EA. New developments in and directions for goal-setting research. European Psychologist. 2007;12(4):290-300. https://doi.org/10.1027/1016-9040.12.4.290

40. Bandura A. Social foundations of thought and action: A Social Cognitive Theory. London: Pearson; 1985.

41. Garba RM, Gadanya MA. The role of intervention mapping in designing disease prevention interventions: A systematic review of the literature. PLoS One. 2017;12(3):e0174438.

https://doi.org/10.1371/journal.pone.0174438

42. De Henauw S, Huybrechts I, De Bourdeaudhuij I, Bammann K, Barba G, Lissner L, et al. Effects of a community-oriented obesity prevention programme on indicators of body fatness in preschool and primary school children. Main results from the IDEFICS study. Obesity Reviews. 2015;16(S2):16-29.

https://doi.org/10.1111/obr.12346

43. Hwang I, Bang KS. Effects of program to promote obesity prevention behaviors on pre-schoolers: Focused on kindergartener in Korea. Journal of Korean Academy of Nursing. 2021;51(2):188-202. https://doi.org/10.4040/jkan.20217

44. Donga Science. Finland, Seinäjoki's city 'Schools on the Move' to lower the obesity rate in children [Internet]. Seoul: Donga Science; 2016 [cited 2021 May 18]. Available from: http://dongascience.donga.com/news.php?idx=13633

45. McLeroy KR, Bibeau D, Steckler A, Glanz K. An ecological perspective on health promotion programs. Health Education and Behavior. 1988;15(4):351-377.

https://doi.org/10.1177/109019818801500401 


\section{Appendix. Program composition and content}

\section{Session 1: Adolescent obesity and the role of schools}

\section{Outline}

- Length: 50 minutes

- Implementer: Health center obesity project manager/staff or school health teacher

- Place: Classroom or assembly hall in the school

\section{Goals}

- Participants understand the importance and methods of adolescent obesity prevention

- Participants understand the importance of the school environment and school life for obesity prevention

3. Necessary items: Questionnaire, portable stadiometer, portable body weight scale, educational materials, worksheet 4. Composition and special notes

\begin{tabular}{|c|c|c|c|c|c|}
\hline Sequence & $\begin{array}{l}\text { Composition } \\
\text { (run-time) }\end{array}$ & Program content & Procedure and special notes & Necessary items & $\begin{array}{c}\text { Method of } \\
\text { implementation }\end{array}$ \\
\hline 1 & $\begin{array}{l}\text { Preliminary } \\
\text { survey } \\
\text { (15 mins) }\end{array}$ & $\begin{array}{l}\text { - Self-report } \\
\text { questionnaire survey } \\
\cdot \text { Height and weight } \\
\text { measurements }\end{array}$ & $\begin{array}{l}\text { - Distribute self-report questionnaire to } \\
\text { participants and collect them when } \\
\text { completed } \\
\text { - Measure the height and weight of each } \\
\text { participant, record them on the } \\
\text { worksheet, and give it to the } \\
\text { participant } \\
\text { - Special note: Height and weight } \\
\text { measurements are performed only in } \\
\text { advance to allow participants to } \\
\text { understand their weight status and } \\
\text { motivate them to participate in the } \\
\text { program. Therefore, if time constraints } \\
\text { are expected, data from students' } \\
\text { health records may be used upon } \\
\text { approval from school administrators }\end{array}$ & $\begin{array}{l}\cdot \text { Questionnaire } \\
\cdot \text { Portable stadiometer } \\
\cdot \text { Portable body weight } \\
\text { scale } \\
\cdot \text { Worksheet }\end{array}$ & \\
\hline 2 & $\begin{array}{l}\text { Group } \\
\text { education } \\
\text { (30 mins) }\end{array}$ & $\begin{array}{l}\text { Status, causes, and } \\
\text { results of adolescent } \\
\text { obesity } \\
\text { - Ways to prevent } \\
\text { adolescent obesity } \\
\text { - Advantages of } \\
\text { preventing adolescent } \\
\text { obesity } \\
\text { - School and obesity } \\
\text { prevention }\end{array}$ & $\begin{array}{l}\text { Provide a lecture using educational } \\
\text { materials (PPTX) } \\
\text { - Special note: The worksheet from the } \\
\text { preliminary survey is used to let each } \\
\text { participant understand his/her weight } \\
\text { status. The lecture on obesity is given } \\
\text { after raising students' interest in } \\
\text { obesity. Since the participants are } \\
\text { typically sensitive to weight and } \\
\text { appearance at their age, implementers } \\
\text { must be careful not to draw or express } \\
\text { attention to a specific student }\end{array}$ & $\begin{array}{l}\cdot \text { Educational materials } \\
\text { (PPTX) }\end{array}$ & - Lecture \\
\hline 3 & $\begin{array}{l}\text { Wrap-up } \\
(5 \text { mins })\end{array}$ & $\begin{array}{l}\text { - Adolescent obesity } \\
\text { and the role of schools }\end{array}$ & $\begin{array}{l}\text { Summarize and emphasize the lecture } \\
\text { content using the educational } \\
\text { materials (PPTX) }\end{array}$ & $\begin{array}{l}\text { - Educational materials } \\
\text { (PPTX) }\end{array}$ & - Lecture \\
\hline
\end{tabular}

PPTX, PowerPoint file. 


\section{Session 2: Healthy eating behaviors at school}

\section{Outline}

- Length: 50 minutes

- Implementer: Health center obesity project manager/staff or school health teacher

- Place: Classroom or assembly hall in the school

2. Goals

- Participants understand how to establish healthy eating behaviors at school

3. Necessary items: Educational materials, worksheets

4. Composition and special notes

\begin{tabular}{|c|c|c|c|c|c|}
\hline Sequence & $\begin{array}{l}\text { Composition } \\
\text { (run-time) }\end{array}$ & Program content & Procedure and special notes & Necessary items & $\begin{array}{l}\text { Method of } \\
\text { implementation }\end{array}$ \\
\hline 1 & $\begin{array}{l}\text { Group } \\
\text { education } \\
\text { (5 mins) }\end{array}$ & $\begin{array}{l}\text { Review of the } \\
\text { content from the } \\
\text { previous session }\end{array}$ & $\begin{array}{l}\text { Give a quiz on the topics from the previous } \\
\text { session (adolescent obesity and the role of } \\
\text { schools) } \\
\text { - Special note: A prize may be given (ex: health } \\
\text { center memento) to induce competition among } \\
\text { participants }\end{array}$ & $\begin{array}{l}\text { Educational } \\
\text { materials (PPTX) }\end{array}$ & - Quiz \\
\hline 2 & $\begin{array}{l}\text { Individual } \\
\text { activity } \\
\text { (10 mins) }\end{array}$ & $\begin{array}{l}\text { Barriers and } \\
\text { solutions to } \\
\text { healthy eating } \\
\text { behaviors at } \\
\text { school }\end{array}$ & $\begin{array}{l}\text { - Guide each participant to write the barriers and } \\
\text { solutions to practicing healthy eating behaviors } \\
\text { at school } \\
\text { - Invite } 2-3 \text { participants to present their } \\
\text { experiences and provide feedback } \\
\text { - Special note: A prize may be given (ex: health } \\
\text { center memento) to boost participants' } \\
\text { motivation to participate }\end{array}$ & - Worksheet & $\begin{array}{l}\text { - Presentation } \\
\cdot \text { Feedback }\end{array}$ \\
\hline 3 & $\begin{array}{l}\text { Group } \\
\text { education } \\
\text { (15 mins) }\end{array}$ & $\begin{array}{l}\text { - Ways to } \\
\text { improve healthy } \\
\text { eating behaviors } \\
\text { at school }\end{array}$ & $\begin{array}{l}\text { - Provide a lecture using educational materials } \\
\text { (PPTX) }\end{array}$ & $\begin{array}{l}\text { Educational } \\
\text { materials (PPTX) }\end{array}$ & - Lecture \\
\hline 4 & $\begin{array}{l}\text { Individual } \\
\text { activity } \\
\text { (15 mins) }\end{array}$ & $\begin{array}{l}\text { Set goals to } \\
\text { improve healthy } \\
\text { eating behaviors } \\
\text { at school }\end{array}$ & $\begin{array}{l}\text { - Guide participants to write their goals to } \\
\text { practice healthy eating behaviors at school } \\
\text { - Invite } 2-3 \text { participants to present their } \\
\text { experience and provide feedback } \\
\text { - Special note: A prize may be given (ex: health } \\
\text { center memento) to boost participants' } \\
\text { motivation to participate }\end{array}$ & - Worksheet & $\begin{array}{l}\text { - Presentation } \\
\cdot \text { Feedback }\end{array}$ \\
\hline 5 & $\begin{array}{l}\text { Wrap-up } \\
(5 \text { mins })\end{array}$ & $\begin{array}{l}\cdot \text { Healthy eating } \\
\text { behaviors at } \\
\text { school }\end{array}$ & $\begin{array}{l}\text { Summarize and emphasize today's lecture } \\
\text { content using the educational materials (PPTX) }\end{array}$ & $\begin{array}{l}\text { - Educational } \\
\text { materials (PPTX) }\end{array}$ & - Lecture \\
\hline
\end{tabular}

PPTX, PowerPoint file. 


\section{Session 3: Increasing physical activity at school}

\section{Outline}

- Length: 50 minutes

- Implementer: Health center obesity project manager/staff or school health teacher

- Place: Classroom or assembly hall in the school

2. Goals

- Participants understand how to improve physical activities at school

3. Necessary items: Questionnaire, educational materials (PowerPoint file), worksheet, poster, resistance band

4. Composition and special note

\begin{tabular}{|c|c|c|c|c|c|}
\hline Sequence & $\begin{array}{l}\text { Composition } \\
\text { (Run-time) }\end{array}$ & Program content & Procedure and special notes & Necessary items & $\begin{array}{c}\text { Method of } \\
\text { implementation }\end{array}$ \\
\hline 1 & $\begin{array}{l}\text { Group } \\
\text { education } \\
\text { (5 mins) }\end{array}$ & $\begin{array}{l}\text { Review of the } \\
\text { content from the } \\
\text { previous session }\end{array}$ & $\begin{array}{l}\text { Give a quiz on the subject from the } \\
\text { previous session (adolescent obesity } \\
\text { and the role of schools) } \\
\text { - Special note: A prize may be given (ex: } \\
\text { health center memento) to induce } \\
\text { competition among participants }\end{array}$ & $\begin{array}{l}\text { Educational } \\
\text { materials (PPTX) }\end{array}$ & - Quiz \\
\hline 2 & $\begin{array}{l}\text { Group } \\
\text { education } \\
\text { (15 mins) }\end{array}$ & $\begin{array}{l}\text { Ways to improve } \\
\text { physical activities at } \\
\text { school }\end{array}$ & $\begin{array}{l}\text { - Provide a lecture using educational } \\
\text { materials (PPTX) } \\
\text { - Demonstrate exercises that can be done } \\
\text { indoors using a resistance band and } \\
\text { invite the participants to try them } \\
\text { - Special note: Display posters in } \\
\text { conspicuous places to encourage } \\
\text { continued improvement in physical } \\
\text { activities after the program }\end{array}$ & $\begin{array}{l}\cdot \text { Educational } \\
\text { materials (PPTX) } \\
\cdot \text { Poster } \\
\cdot \text { Resistance band }\end{array}$ & $\begin{array}{l}\cdot \text { Lecture } \\
\cdot \text { Demonstration } \\
\cdot \text { Practice } \\
\text { (in-school } \\
\text { campaign) }\end{array}$ \\
\hline 3 & $\begin{array}{l}\text { Individual } \\
\text { activity } \\
\text { (10 mins) }\end{array}$ & $\begin{array}{l}\text { Barriers and } \\
\text { solutions to } \\
\text { improving physical } \\
\text { activities at school }\end{array}$ & $\begin{array}{l}\text { - Guide each participant to write the } \\
\text { barriers and solutions to improving } \\
\text { physical activities at school } \\
\text { - Invite } 2-3 \text { participants to present their } \\
\text { experiences and provide feedback } \\
\text { - Special note: A prize may be given (ex: } \\
\text { health center memento) to boost } \\
\text { participants' motivation to participate }\end{array}$ & - Worksheet & $\begin{array}{l}\cdot \text { Presentation } \\
\text { - Feedback }\end{array}$ \\
\hline 4 & $\begin{array}{l}\text { Individual } \\
\text { activity } \\
\text { (5 mins) }\end{array}$ & $\begin{array}{l}\text { Set goals to improve } \\
\text { physical activities at } \\
\text { school }\end{array}$ & $\begin{array}{l}\text { Guide participants to write their goals } \\
\text { to improve physical activities at school } \\
\text { - Invite } 2-3 \text { participants to present their } \\
\text { experience and provide feedback } \\
\text { - Special note: A prize may be given (ex: } \\
\text { health center memento) to boost } \\
\text { participants' motivation to participate }\end{array}$ & - Worksheet & $\begin{array}{l}\text { - Presentation } \\
\text { - Feedback }\end{array}$ \\
\hline 5 & $\begin{array}{l}\text { Post-survey } \\
\text { (10 mins) }\end{array}$ & $\begin{array}{l}\text { Self-report } \\
\text { questionnaire } \\
\text { survey }\end{array}$ & $\begin{array}{l}\text { Distribute self-report questionnaire to } \\
\text { participants and collect them when } \\
\text { completed } \\
\text { - Special note: If available, briefly } \\
\text { introduce the obesity prevention } \\
\text { program for adolescents currently } \\
\text { provided at the health center }\end{array}$ & - Questionnaire & \\
\hline 6 & $\begin{array}{l}\text { Wrap-up } \\
(5 \text { mins })\end{array}$ & $\begin{array}{l}\text { - Improve physical } \\
\text { activities at school }\end{array}$ & $\begin{array}{l}\text { Summarize and emphasize today's } \\
\text { lecture content using educational } \\
\text { materials (PPTX) }\end{array}$ & $\begin{array}{l}\text { Educational } \\
\text { materials (PPTX) }\end{array}$ & - Lecture \\
\hline
\end{tabular}

PPTX, PowerPoint file. 


\section{Program material example}

\section{Educational materials (PowerPoint file)}

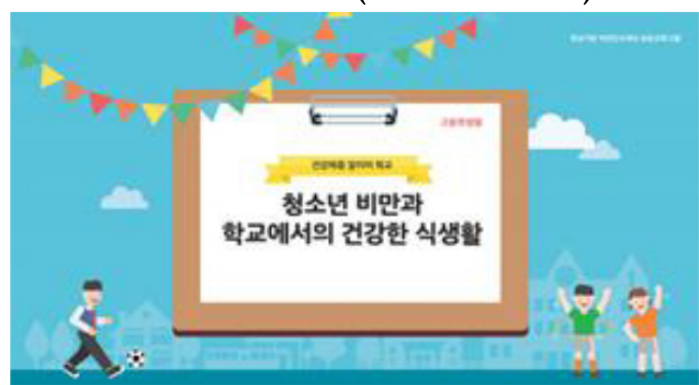

\section{Operating manual}

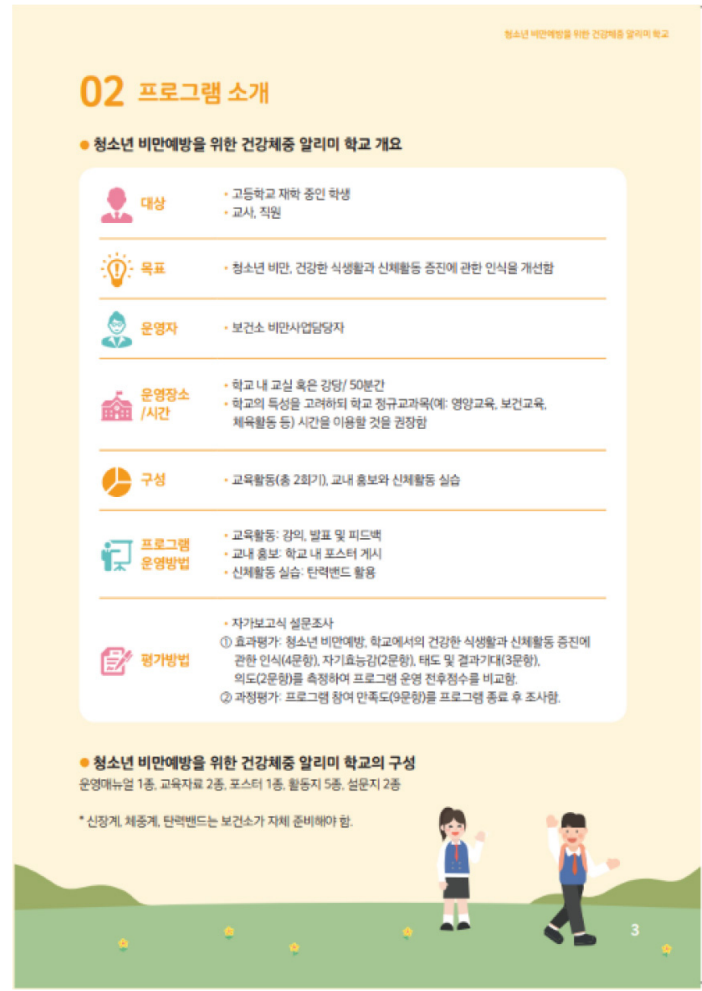

\section{Worksheet}

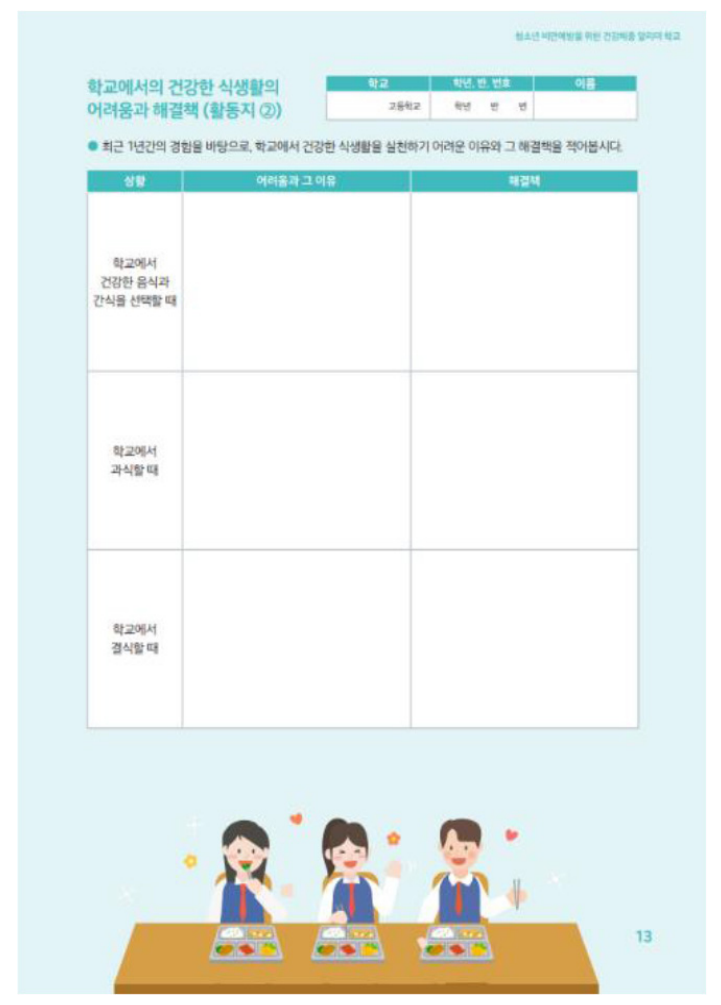

\section{Poster}

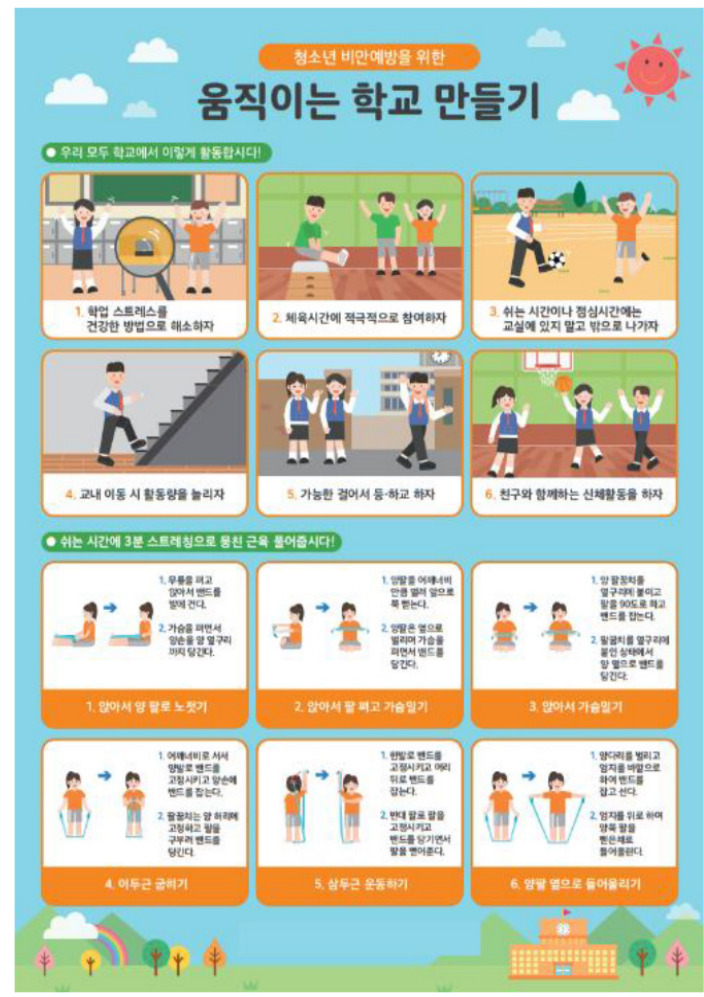

